Preparations of murine recombinant interferon (Mu-rIFN)-alpha, -beta and -gamma were assessed for their influence on in vitro growth of mast cells from normal mouse spleen cells (Sp C). Mast cell growth was inhibited by $\mathrm{Mu}$-rIFNs when Sp C were exposed throughout the entire culture period to Mu-rIFNs. The most potent inhibitor of mast cell growth was Mu-rIFN- $\gamma$, followed by Mu-rIFN- $\beta$; Mu-rIFN- $\alpha$ had little effect. When added to IC-2 cells, clonal mast cell progenitor, both Mu-rIFN- $\beta$ and $-\gamma$ significantly inhibited proliferative response of the target cells. The suppressive effect of Mu-rIFNs on IC-2 cells was selectively abolished by monoclonal antibodies against Mu-rIFN- $\boldsymbol{\beta}$ and $-\gamma$.

Key words: Interferon, Mast cell, Mice

\section{Inhibitory effect of interferon-beta on mouse spleen-derived mast cells}

\author{
S. Konno, ${ }^{1, C A}$ M. Adachi, ${ }^{1}$ K. Asano, ${ }^{2}$ \\ K. Okamoto ${ }^{2}$ and T. Takahashi ${ }^{1}$ \\ ${ }^{1}$ First Department of Internal Medicine, and \\ ${ }^{2}$ Department of Medical Biology, School of \\ Medicine, Showa University, Hatanodai, \\ Shinagawa-ku, Tokyo 142, Japan
}

${ }^{\mathrm{CA}}$ Corresponding Author

\section{Introduction}

Interferons (IFNs) are well known to be a family of inducible proteins secreted by several types of cells in response to viruses and other stimuli. It is also generally accepted that IFNs can be divided into three different subclasses, IFN $-\alpha,-\beta$ and $-\gamma$ based on their structure, cellular origin and biological properties.

The effect of IFNs on cell proliferation was examined extensively by many investigators and IFN- $\alpha$ and $-\gamma$ have been shown to suppress the in vitro proliferation and/or differentiation of human pulripotent hemopoietic progenitor cells and of committed progenitor cells. ${ }^{1-3}$ Recently, Nafzigar et al. ${ }^{4}$ using normal mouse bone marrow cells, examined the effect of IFN- $\gamma$ on mast cell growth and reported that IFN- $\gamma$ strongly inhibited their growth when bone marrow cells were exposed throughout the entire culture period to IFN- $\gamma$ which seemed to exert its inhibitory activity on mast cell progenitors. There is, however, no evidence for a direct effect of IFN- $\gamma$ on mast cell progenitors. Furthermore, no information is yet available concerning the effects of IFN $\alpha$ and $-\beta$ on mast cell growth and proliferation.

The aim of the present study, therefore, is to evaluate the in vitro effects of IFN- $\alpha$ and $-\beta$ on mast cells. In addition, studies were performed to investigate whether an inhibitory activity of IFN- $\gamma$ on mast cell growth was due to a direct effect on progenitor cells.

\section{Materials and Methods}

Mice: Male BALB/c mice, 7 weeks old, were purchased from Charles River Japan Inc., Atsugi, Japan.

Cell line: Clonal mast cell progenitor IC-2 cell line was kindly supplied by Cell Bank, Riken Gene Bank, Ibaragi, Japan.

IFN and monoclonal antibody to IFN: Murine-recombinant IFN (Mu-rIFN)- $\alpha$ (Spe. Act.: $1.1 \times 10^{6}$ $\mathrm{U} / \mathrm{ml}$ ) and $-\beta$ (specific activity $1.1 \times 10^{6} \mathrm{U} / \mathrm{ml}$ ) were purchased from Lee Biomolecular Research Lab., Inc., San Diego, CA. Mu-rIFN- $\gamma$ (specific activity $1.9 \times 10^{6} \mathrm{U} / \mathrm{ml}$ ) was kindly provided by Toray (Kanagawa, Japan). To neutralize the activity of Mu-rIFNs, $25 \mu \mathrm{g}$ of monoclonal antibodies to Mu-rIFN- $\beta$ (Lee Biomolecular Research Lab. Inc.) and to Mu-rIFN- $\gamma$ (Genzyme Corp., Cambridge, MA) were incubated with $100 \mu$ lof the appropriate $\mathrm{Mu}$-rIFN preparations for $90 \mathrm{~min}$ at $37^{\circ} \mathrm{C}$ just before use.

Induction of mast cells from normal mouse spleen cells: Spleen cell suspension (Sp C) was prepared as described previously. ${ }^{6}$ The cells were adjusted to $5 \times 10^{6}$ cells $/ \mathrm{ml}$ or $10 \times 10^{6}$ cells $/ \mathrm{ml}$ in RPMI-1640 medium (Flow Lab., Irvine, Scotland) supplemented with $10 \%$ foetal calf serum (Bocknek, Canada), $25 \mathrm{mM}$ HEPES, $200 \mathrm{mM}$ L-glutamine, $100 \mathrm{U} / \mathrm{ml}$ penicillin $100 \mu \mathrm{g} / \mathrm{ml}$ streptomycin, and $30 \%$ interleukin 3 culture supplement (Collaborative Biomedical products, Bedford, MA). The cells $(1 \mathrm{ml} /$ well $)$ were 
incubated in 24-well culture plates (Nunc, Intermed, Denmark) at $37^{\circ} \mathrm{C}$ in a humidified atmosphere with $5 \% \mathrm{CO}_{2}$.

IFN treatment: $\mathrm{Mu}$-rIFNs were added to cultured cells at seeding and then every 4 days, when the culture medium was replaced with fresh medium. To study the effects of Mu-rIFNs at different stages of mast cell growth, another series of experiments was carried out, in which Mu-rIFNs were added at seeding or 10 days after seeding.

Cell counts: Every 4 days, the growth of cells was measured by counting cells with a hemocytometer. Cell viability was determined by trypan blue exclusion. Mast cells were counted by a staining method with alcian blue specific for counting basophils and mast cells. ${ }^{7}$

Cell proliferation: IC- 2 cells at a concentration of $2 \times 10^{5}$ cells $/ \mathrm{ml}$ were introduced into each well of 96-well flat-bottomed culture plates (Nunc, Intermed) that contained $\mathrm{Mu}$-rIFNs in a final volume of $0.2 \mathrm{ml}$. The plate was maintained at $37^{\circ} \mathrm{C}$ in a humidified atmosphere with $5 \% \mathrm{CO}_{2}$. After $40 \mathrm{~h}$, $1.0 \mu \mathrm{Ci}$ of ${ }^{3} \mathrm{H}$-thymidine (specific activity $25 \mathrm{Ci} / \mathrm{mM}$, Amersham International Plc, Buckinghamshire, UK) was added and the plate was maintained for a further $8 \mathrm{~h}$. Cell proliferation was assessed by determination of the rate of incorporation of ${ }^{3} \mathrm{H}$-thymidine into DNA as described previously. ${ }^{6}$

Statistical analysis: Data from control and experimental groups were compared by Student's $t$-test.

\section{Results}

Influence of IFNs on mast cell growth: To examine effects of $\mathrm{Mu}-\mathrm{rIFNs}$ on mast cell induction, $10 \times 10^{6} \mathrm{Sp} \mathrm{C}$ were cultured in the presence of either IFN- $\alpha,-\beta$ or $-\gamma(100 \mathrm{U} / \mathrm{ml}$ each $)$, and the numbers of viable cells and mast cells were counted. As the culture time went on, viable cell numbers decreased gradually in the culture (Fig. 1A). When Sp C were cultured without Mu-rIFNs (Control), the mast cell numbers were gradually increased, peaked on the sixteenth day (Fig. 1B). In contrast to the results obtained in cultures exposed to Mu-rIFN- $\alpha$, a statistically significant suppression of mast cell growth was observed when $\mathrm{Sp} C$ were exposed throughout the entire culture period to Mu-rIFN- $\beta$ and $-\gamma$ (Fig. 1B).

The second experiments were carried out to examine whether mast cell growth inhibition by $\mathrm{Mu}-\mathrm{rIFN}-\beta$ and $-\gamma$ was associated with concentration of Mu-rIFNs added to cultures. To accomplish this, $5 \times 10^{6} \mathrm{Sp} \mathrm{C}$ were cultured in the presence of four different doses of $\mathrm{Mu}-\mathrm{rIFNs}$ and the number of mast cells was counted. As shown in Fig. 2, dose-dependent suppression was observed: 50 and $100 \mathrm{U} / \mathrm{ml}$ of $\mathrm{Mu}-\mathrm{rIFN}-\beta$ failed to suppress mast cell growth but 500 and $1000 \mathrm{U} / \mathrm{ml}$ strongly suppressed them. The data in Fig. 2 also indicated that the suppression exerted by $\mathrm{Mu}-\mathrm{rIFN}-\gamma$ was stronger than that by Mu-rIFN- $\beta$.

The third experiments were designed to examine the effects of Mu-rIFNs in different stages of mast cells. As shown in Fig. 3, addition of $\mathrm{Mu}-\mathrm{rIFN}-\beta$ and $-\gamma(1000 \mathrm{U} / \mathrm{ml}$ each $)$ at seeding of $5 \times 10^{6} \mathrm{Sp} \mathrm{C}$ significantly inhibited mast cell
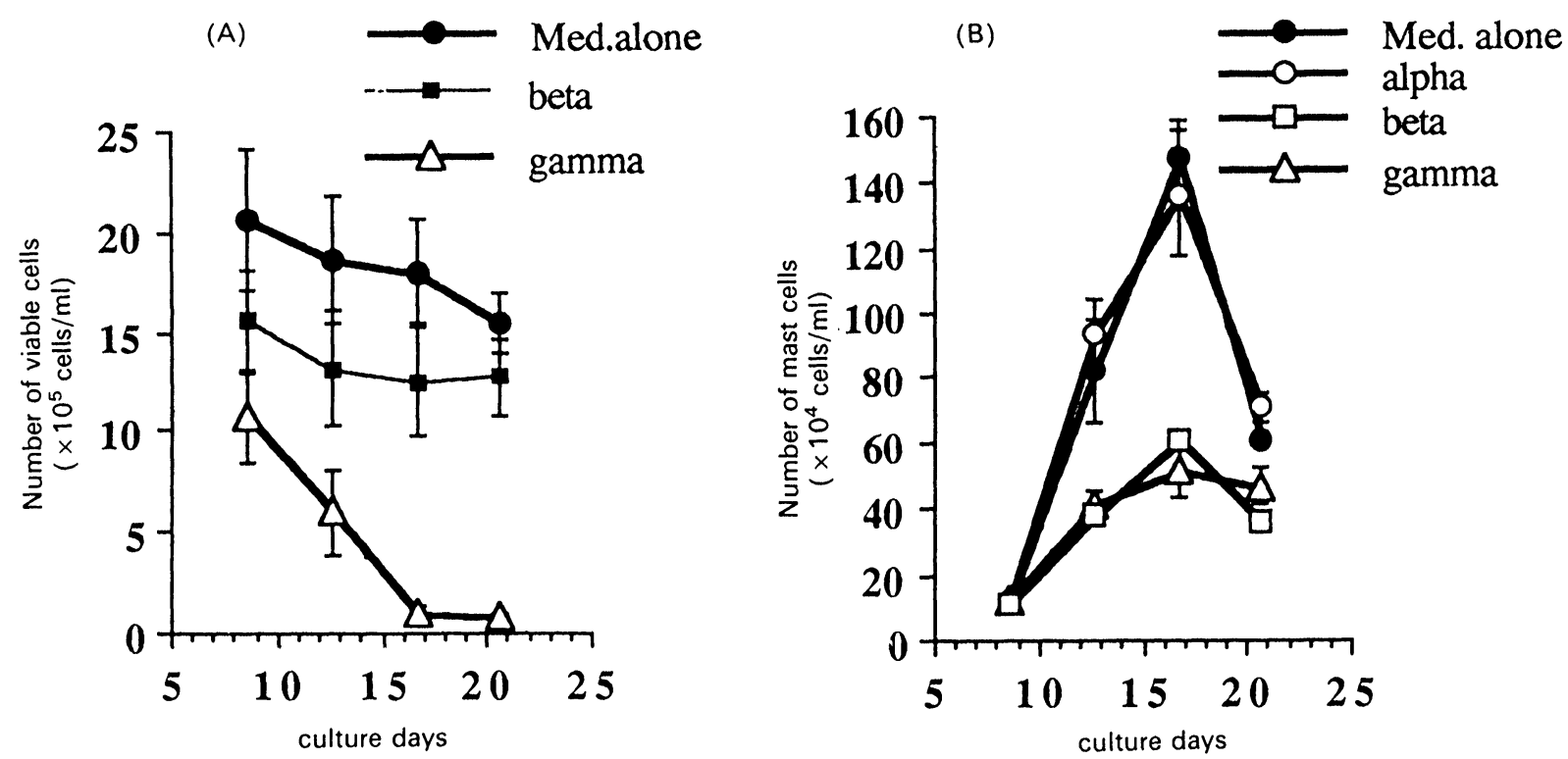

FIG. 1. Influence of interferons on viable cells and mast cell induction in cultured murine splenocytes. MU-rIFNs $(1000 \mathrm{U} / \mathrm{ml}) \mathrm{were}$ added at the time of seeding spleen cells $\left(10 \times 10^{6} \mathrm{cells} / \mathrm{ml}\right)$ and then every 4 days, when the culture medium was replaced with the fresh medium. Results are expressed as the mean \pm S.E. of two different experiments. 


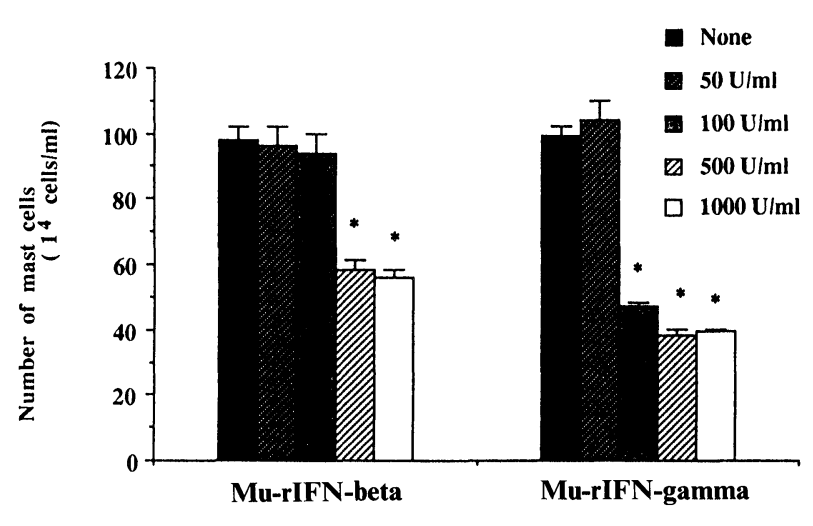

FIG. 2. Effects of murine-recombinant interferons (Mu-rIFNs) on mast cell growth. Mu-rlFNs were added at the time of seeding spleen cells $\left(5 \times 10^{6}\right.$ cells $\left./ \mathrm{ml}\right)$ and then every 4 days, when the culture medium was replaced with a fresh medium. Mast cell growth was evaluated 16 days after culture. Results are expressed as the mean \pm S.E. of two different experiments. Asterisks indicate $p<0.05$ versus control (None).

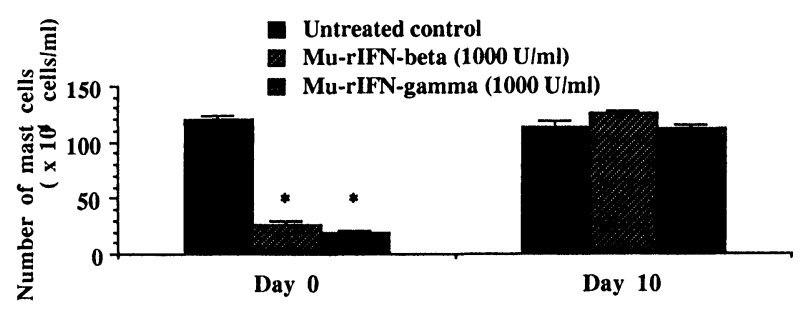

FIG. 3. Effects of adding murine-recombinant interferons (Mu-rIFNs) a different times after seeding spleen cells. Mu-rIFNs were added to the culture medium on days 0 and 10 , and mast cell growth was evaluated on day 16. The values are the mean $\pm \mathrm{S}$.E. of two different experiments. Asterisks indicate $p<0.05$ versus control.

growth. However, no such inhibition was observed when Mu-rIFNs were added to the cells after 10 days of culture.

Influence of Mu-rIFNs on mast cell progenitors: The final experiments were carried out to examine whether Mu-rIFN- $\beta$ and $-\gamma$ exerted their inhibitory effects described above by acting directly on mast cell precursors. For this purpose, IC- 2 cells, mast cell progenitors were cultured in the presence of Mu-rIFNs and cell proliferation was examined. As shown in Table 1, addition of Mu-rIFN- $\beta$ and $-\gamma$ significantly inhibited IC- 2 cell proliferation in dose

Table 1. Effect of interferons (IFN) on the proliferation of IC-2 cell line

\begin{tabular}{clc}
\hline $\begin{array}{c}\text { Dose of IFN } \\
(\mathrm{U} / \mathrm{ml})\end{array}$ & \multicolumn{2}{c}{ Proliferation (cpm \pm S.E. $)$} \\
\cline { 2 - 3 } & \multicolumn{1}{c}{ IFN- $\beta$} & IFN- $\gamma$ \\
\hline None & $272452.0 \pm 4401.5$ & $252742.0 \pm 10430.1$ \\
$($ control $)$ & & \\
50 & $262153.7 \pm 21504.1$ & $254093.3 \pm 2218.7$ \\
100 & $221744.0 \pm 7053.4$ & $112901.7 \pm 17508.0^{*}$ \\
500 & $206167.1 \pm 9350.1 *$ & $92088.1 \pm 4032.5^{*}$ \\
1000 & $130673.4 \pm 38264.0 *$ & $47678.3 \pm 3504.4^{*}$ \\
\hline
\end{tabular}

Clonal mast cell precursors, IC-2 cells, at a concentration of $2 \times 10^{5}$ cells $/ \mathrm{ml}$ were cultured with ${ }^{3} \mathrm{H}$-thymidine in a culture plate containing $\mathrm{Mu}$-rIFNs. Asterisks indicate $p<0.05$ versus control.
Table 2. Specific inactivation of the suppressive influence of murine-recombinant interferons (Mu-rIFNs) $-\beta$ and $-\gamma$ on IC-2 cell proliferation by pre-incubation of the interferons with their respective antibodies

\begin{tabular}{lc}
\hline & $\begin{array}{c}{ }^{3} \mathrm{H} \text {-thymidine uptake } \\
(\mathrm{cpm} \pm \text { S.E. })\end{array}$ \\
\hline Control (medium alone) & $276728.3 \pm 8228.7$ \\
Mu-rIFN- $\beta\left(10^{3} \mathrm{U} / \mathrm{ml}\right)$ & $76454.3 \pm 6544.4^{*}$ \\
Mu-rIFN- $\beta+$ anti-IFN-beta & $279116.3 \pm 4370.3$ \\
Mu-rIFN- $\gamma\left(10^{3} \mathrm{U} / \mathrm{ml}\right)$ & $41995.0 \pm 3011.1^{*}$ \\
Mu-rIFN- $\gamma+$ anti-IFN-gamma & $214557.3 \pm 7428.1$ \\
\hline
\end{tabular}

Preparations of $\mathrm{Mu}$-rIFNs were preincubated for $90 \mathrm{~min}$ at $37^{\circ} \mathrm{C}$ with or without $10^{4}$ neutralizing units of monoclonal antibodies to $\mathrm{Mu}-$ rIFN $-\beta$ or $\mathrm{Mu}-\mathrm{rIFN}-\gamma$. Asterisks indicate $p<0.05$ versus control.

dependent manner. These inhibitory actions were completely abolished when $\mathrm{Mu}$-rIFNs were preincubated with monoclonal antibodies suitable to the appropriate IFN type (Table 2).

\section{Discussion}

The results of this study demonstrated that: (1) both $\operatorname{rIFN}-\beta$ and $-\gamma$, but not $-\alpha$, are potent inhibitors of murine mast cell proliferation; (2) rIFN- $\beta$ and $-\gamma$ exert their inhibitory activity on mast cell progenitors, but not on mature mast cells. These conclusions are supported by the following observations: firstly, when $\mathrm{Sp} C$ were exposed throughout the entire culture period to rIFN- $\beta$ and $-\gamma$, a statistically significant and dose-dependent suppression of mast cell growth was observed, whereas no such inhibition was observed when $\mathrm{Mu}-\mathrm{rIFN}-\alpha$ was added to the cultures at seeding of Sp C. Secondly, addition of rIFN- $\beta$ and $-\gamma$ to the culture medium at seeding strongly inhibited mast cell growth. However, addition of rIFNs 10 days after seeding, when differentiation of precursors and proliferation of immature mast cells are progressed, did not affect mast cell growth, as assessed by mast cell number observed on day 16. Finally, proliferation of IC-2 cells, clonal mast cell progenitors, was strongly inhibited when the cells were cultured in vitro with $\operatorname{rIFN}-\beta$ and $-\gamma$. This inhibition was completely neutralized when the IFNs were pre-incubated with a monoclonal antibody directed to the appropriate IFN type.

As far as we know, the present experiments are the first to demonstrate that IFN- $\gamma$ exerts its antiproliferative effect on mast cells by acting directly on their precursors and to show that IFN- $\beta$, but not IFN- $\alpha$ has biological effects on mast cells similar to those of IFN- $\gamma$.

IFN- $\beta$ could exert its anti-proliferative effect by acting directly on mast cell precursors and various mechanisms can be envisaged. IFN- $\beta$ might act on Ia antigen and result in inhibition of mast cell 
growth. Indeed, under certain conditions, Ia antigen was shown to be involved in the negative regulation of cell growth. ${ }^{8,9}$ Alternatively, downregulation of oncogene expression, demonstrated by the addition of IFNs to in vitro experimental models, ${ }^{10}$ might also explain the anti-proliferative activity of IFN- $\beta$ on mast cells. The possibility that other cells present in early cultures could be involved in the mediation of inhibitory effect of IFN- $\beta$ cannot be excluded, since a role of accessory cells such as lymphocytes and monocytes was reported in the suppression of normal erythropoiesis by IFN- $\gamma{ }^{11}$ It is well known that IFNs exert their pleiotropic effects by interacting with specific receptors on the surface membrane. Nafzigar et al. ${ }^{4}$ reported that IFN- $\gamma$ inhibits in vitro mast cell growth by formation of IFN- $\gamma$-receptor complex, suggesting that IFN- $\beta$ binds to specific receptor for IFN- $\beta$ differed from that for IFN- $\gamma^{12,13}$ on mast cell precursors and result in inhibition of mast cell growth. Anyway, further experimentations are needed to clarify the precise mechanisms by which IFN- $\beta$ inhibits mast cell growth.

IFNs have been employed successfully in the treatment of some infectious diseases and cancers. ${ }^{14}$ So far, no clinical applications have been made of their potent immunoregulatory effects, although the inhibitory effect of IFNs on the mycotic disease induced by Aspergilus fumigatus ${ }^{15}$ and on lepromatous leprosy ${ }^{16}$ may depend on the activation of macrophages and T-cells, respectively. Mast cells are now considered to play a pivotal role not only in allergic reactions but also in many pathological immune responses. ${ }^{17,18}$ It is also well known that infiltration of mast cells and the presence of mast cell-derived soluble mediators in the presence of asthma and atopic allergy are well correlated with the severity of the diseases. From these reports, whatever the mechanisms involved, our in vitro results suggest that IFN- $\beta$ and $-\gamma$ could act in vivo as inhibitory factors of mast cell proliferation and that these lymphokines could be of interest in the treatment of asthma and atopic allergy.

\section{References}

1. Broxmeyer HE, Lu L, Platzer E, Feit C, Juliano L, Rubin BY. Comparative analysis of the influences of human $\gamma, \alpha$ and $\beta$ interferons on human multipotential (CFU-GEMM), erythroid (BFU-E) and granulocyte-macrophage (CFU-GM) progenitor cells. I Immunol 1983; 131: 1300-1305.

2. Ganser A, Carlo SC, Greher J, Volkers B, Hoelzer D. Effect of recombinant interferons alpha and gamma on human bone marrow-derived megakaryocytic progenitor cells. Blood 1987; 70: 1173-1179.

3. Raefsky EL, Platanias LC, Zoumbos NC, Young NS. Studies of interferon as a regulator of hematopoietic cell proliferation. J Immunol 1985; 135: 2507-2512.

4. Nafziger J, Arock M, Guillosson JJ, Wietzerbin J. Specific high-affinity receptors for interferon- $\gamma$ on mouse bone marrow-derived mast cells: inhibitory effect of interferon- $\gamma$ on mast cell precursors. Eur J Immunol 1990 20: 113-117.

5. Koyasu S, Yodoi J, Nikaido T, et al. Expression of interleukin 2 receptor on interleukin 3-dependent cell lines. J Immunol 1986; 136: 984-987.

6. Konno S, Adachi M, Asano K, Kawazoe T, Okamoto K, Takahashi T. Influence of roxithromycin on cell-mediated immune responses. Life $\mathrm{Sci}$ 1992; 51: PL107-PL112.

7. Gilbert $\mathrm{H}$, Sornstein L. Basophil counting with a new staining method using alcian blue. Blood 1975; 46: 279-286.

8. Pelus LM, Saletan S, Silver RT, Moore MA. Expression of Ia-antigens on normal and chronic myeloid leukemic human granulocyte macrophage colony-forming cells (CFU-GM) is associated with the regulation of cel proliferation by prostaglandin E. Blood 1982; 59: 284-292.

9. Wong GH, Clark LI, Hamilton JA, Schrader JW. P cell stimulating factor and glicocorticoids oppose the action of interferon- $\gamma$ in inducing Ia antigens on T-dependent mast cells (P cells). J Immunol 1984; 133: 2043-2050.

10. Kimchi A, Resnitzky D, Ber R, Gat G. Recessive genetic deregulation abrogates c-myc suppression by interferon and is implicated in oncogenesis. Mol Cell Biol 1988; 8: 2828-2836.

11. Mamus SW, Beck SS, Zanjani ED. Suppression of normal human erythropoiesis by gamma interferon in vitro. Role of monocytes and T-lymphocytes. J Clin Invest 1985; 75: 1496-1503.

12. Orchansky P, Novick D, Fischer DG, Rubinstein M. Type I and Type II interferon receptors. I Interferon Res 1984; 4: 275-282.

13. Celada A. The interferon gamma receptor. Lymphokine Res 1988; 7: 61-73.

14. Friedman RM. Interferons. In: Oppenheim JJ, Schevach EM, eds Immunophysiology. New York: Oxford University Press, 1990; 194-209.

15. Maheshwari RK, Tandon RN, Rhodes-Feuillette A, Mahou G, Badillet G, Friedman RM. Interferon inhibits Aspergillus fumigatus growth in mice: an activity against an extracellular infection. I Interferon Res 1987; 8: 35-44.

16. Nathan CF, Kaplan G, Levis WR, et al. Local and systemic effects of intradermal recombinant interferon in patients with lepromatous leprosy. $N$ Engl J Med 1986; 315: 6-14.

17. Stevens RL, Austen KF. Recent advances in the cellular and molecular biology of mast cells. Immunol Today 1989; 10: 381-386.

18. Galli SJ. New insights into 'The riddle of the mast cells': microenvironmental regulation of mast cell development and phenotypic heterogeneity. Lab Invest 1990; 62: 5-33.

ACKNOWLEDGEMENTS. We thank Dr T. Ohno, Cell Bank, Riken Gene Bank, for providing the IC-2 cell line. We also acknowledge Dr Kajita (Toray Industries, Inc. Basic Research Laboratories) for a kind gift of recombinant murine interferon- $\gamma$.

Received 3 February 1993 accepted in revised form 7 April 1993 


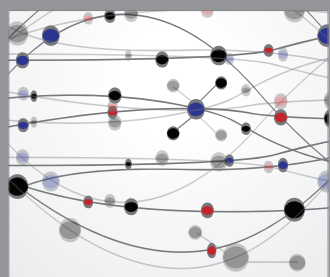

The Scientific World Journal
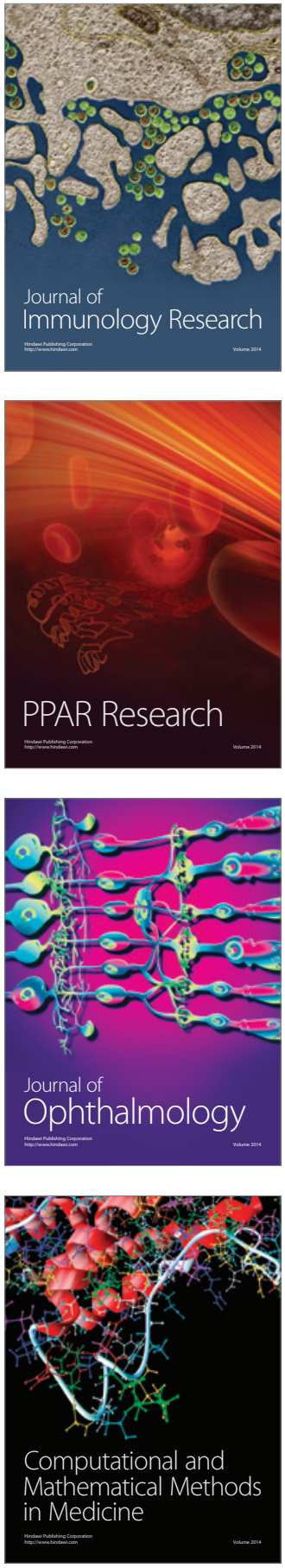

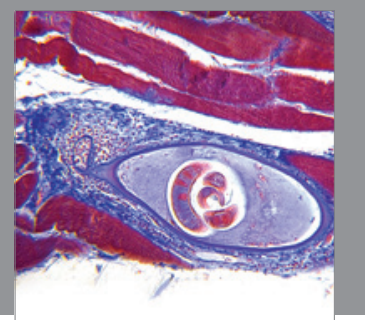

Gastroenterology

Research and Practice
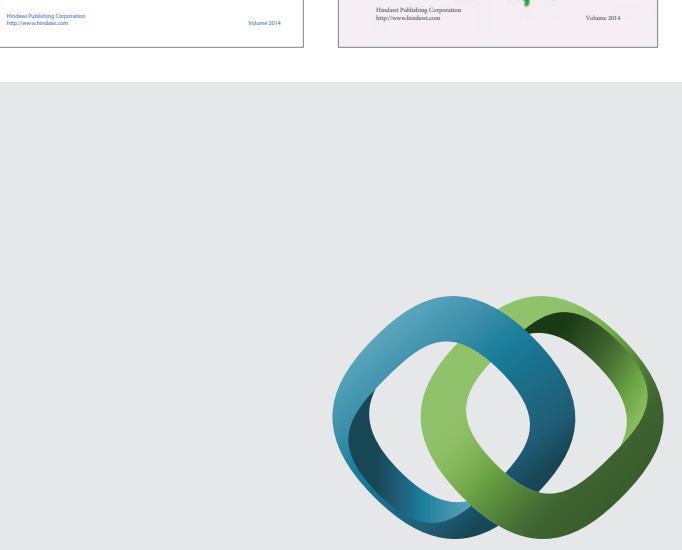

\section{Hindawi}

Submit your manuscripts at

http://www.hindawi.com
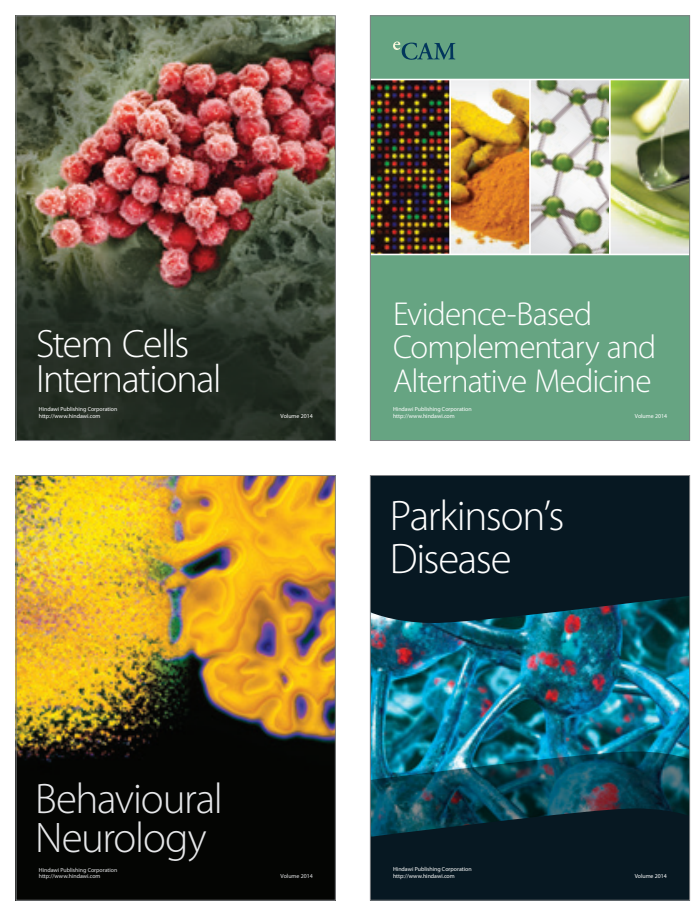

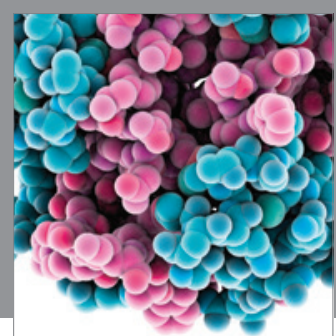

Journal of
Diabetes Research

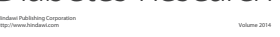

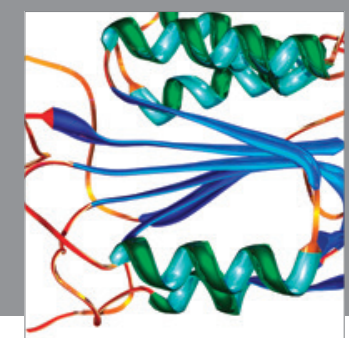

Disease Markers
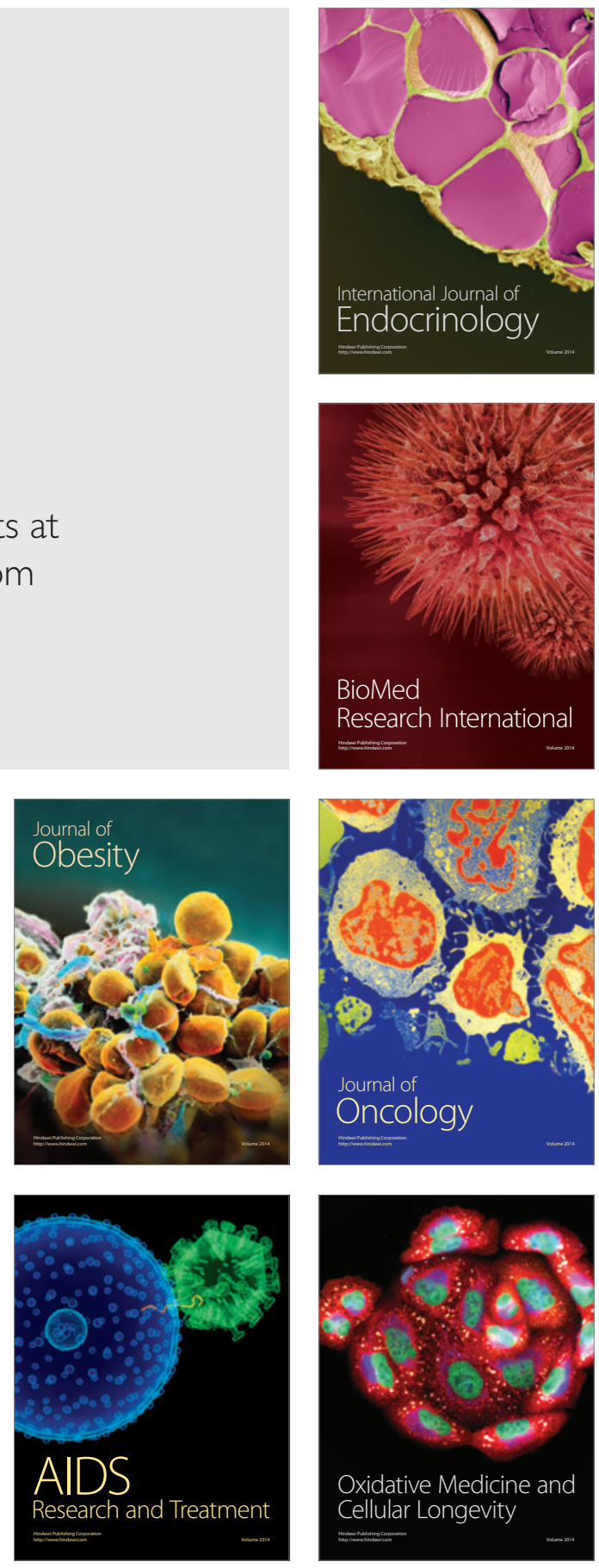